\title{
Inclusion of various amounts of steam-flaked soybeans in lactating dairy cattle diets
}

\author{
H. R. Bruns, A. R. Hippen, ${ }^{1}$ K. F. Kalscheur, ${ }^{2}$ and D. J. Schingoethe ${ }^{3}$ \\ Dairy Science Department, South Dakota State University, Brookings 57007-0647
}

\begin{abstract}
Whereas most soybean feedstuffs have been extensively investigated for use in ruminant diets, a lack of information exists regarding steam-flaked soybeans (SFSB). This research evaluated various inclusion rates of SFSB in diets for lactating dairy cattle. Twelve multiparous Holstein cows (103 $\pm 39 \mathrm{~d}$ in milk) were used in a $4 \times 4$ Latin square experiment consisting of 28 -d periods, $14 \mathrm{~d}$ for diet transitioning followed by a 14-d sampling period. Treatments were inclusion of SFSB at $0,5,10$, and $15 \%$ of dietary dry matter (DM), replacing a mixture of soybean meal, soy hulls, calcium salts of fatty acids, and choice white grease. Animals were fed lactating dairy cow diets formulated to be isonitrogenous and isoenergetic, containing $60 \%$ of DM as forage and $40 \%$ of DM as concentrate. Dry matter intake $($ mean $=28.8 \mathrm{~kg} / \mathrm{d})$, milk production $(42.2 \mathrm{~kg} / \mathrm{d})$, milk fat percentage $(3.52 \%)$, and feed efficiency $(1.43 \mathrm{~kg}$ of energy-corrected milk/kg of DM intake) were similar across all treatments. Milk protein $(2.98 \%)$ and lactose (4.87\%) were also unaffected by the amount of SFSB in the diet. Milk urea nitrogen concentration decreased linearly as the amount of SFSB in the diet increased. Unlike some other soybean supplements, feeding SFSB did not increase trans-11 C18:1 or cis-9,trans-11 conjugated linoleic acid, but instead resulted in increased cis-9,cis-12 C18:2 and $\alpha-C 18: 3$. Body weights (752 kg) and body condition scores (3.17) were similar with all diets. This research demonstrated that SFSB can be substituted for soybean meal and commercial fat sources while maintaining milk and milk component production and decrease milk urea nitrogen concentration.
\end{abstract}

Key words: steam-flaked soybean, fat, lactating cow

\footnotetext{
Received January 26, 2015.

Accepted June 17, 2015.

${ }^{1}$ Deceased.

${ }^{2}$ Present address: USDA, ARS, US Dairy Forage Research Center, Madison, WI 53706.

${ }^{3}$ Corresponding author: david.schingoethe@sdstate.edu
}

\section{INTRODUCTION}

High-producing dairy cattle require higher RUP content than is provided by solvent-extracted soybean meal (NRC, 2001). Heat treatment of soybean products, such as full-fat whole soybeans, has the potential to increase RUP content as much as $70 \%$ (Waltz and Stern, 1989), with extrusion and roasting being the 2 most widely used processes in the US feed industry. Roasting is usually a relatively inexpensive method to heat treat, but uneven heating has often resulted in inconsistent results. Some researchers (Stern et al., 1985; Scott et al., 1991) did not find increased milk production when cows were fed roasted or extruded soybeans in place of raw soybeans or soybean meal. However, Faldet and Satter (1991) and Knapp et al. (1991) observed increased milk production when feeding roasted soybeans in place of soybean meal or raw soybeans. Neves et al. (2006) observed no increase in milk production when cows were fed extruded soybeans, whereas Schingoethe et al. $(1988,1996)$ obtained higher milk production from cows fed extruded soybeans in place of soybean meal. Extrusion provides a more uniform product than roasting but is often a slower, more costly procedure and may sometimes cause slight milk fat depression due to rupturing of fat cells in the beans during extrusion. The result is a greater increase in the unsaturated FA content of milk fat (Schingoethe et al., 1996; Chouinard et al., 1997b), including cis-9,trans-11 CLA (Ramaswamy et al., 2001; AbuGhazaleh et al., 2004), than other heating methods. Other methods of heat processing of soybeans or soybean meal are used in the feed industry, but few have refereed published documentation. This is also true for steam flaking of soybeans, which was our reason for evaluating it in diets of lactating cows.

In addition to increased RUP by heat-treating soybeans, these products can also be a source of dietary fat as a means to increase energy density of the diet, thus increase energy intake and possibly increase milk production. Raw (unheated) full-fat soybeans contain approximately $20 \%$ fat; however, 50 to $60 \%$ of that fat is derived from PUFA (Chouinard et al., 1997a; AbuGhazaleh et al., 2004; Lundy et al., 2004). Diets 
high in unsaturated FA can lead to diet-induced milk fat depression (Bauman and Griinari, 2003). This was usually not observed when fed heat-treated full-fat soybeans (Faldet and Satter, 1991; Pires et al.,1996; AbuGhazaleh et al., 2002), but occurred when soybean oil was supplemented in the diet (Mohamed et al., 1988; Zheng et al., 2005; AlZahal et al., 2008) because the FA were more available in the rumen for interfering with biohydrogenation. Supplementing with extruded soybeans decreased short- and medium-chain FA as well as SFA in milk fat and increased content of longchain and unsaturated FA (AbuGhazaleh et al., 2002). Additionally, feeding extruded soybeans led to 118 and $136 \%$ increases in cis-9,trans-11 CLA and trans-11 C18:1, respectively, when compared with the control diet. Rupturing of some oil cells in the soybeans during the extrusion process likely contributes to its greater effects on FA composition of milk fat than observed with roasted soybeans (Reddy et al., 1994). Although we did not directly compare steam-flaked soybeans (SFSB) to extruded soybeans in the current study, we hypothesized that SFSB will have a less pronounced effect on the milk FA content as extruded soybeans, but the increased RUP of SFSB should increase milk protein production. Whereas most other heat-treated full-fat soybean products have been evaluated for their feeding value and effects on production, data regarding SFSB is very limited. Thus, the objective of our research was to evaluate the effects of feeding SFSB to dairy cows at $0,5,10$, and $15 \%$ of dietary DM on production parameters as well as milk fat composition. As a result of the heat-treatment or steam-flaking process, we hypothesized SFSB to have an increased RUP content that would thus result in increased milk production (Bruns et al., 2011). Additionally, we expected milk fat to contain greater amounts of trans-11 C18:1 and cis-9,trans-11 C18:2 in cows fed SFSB than when fed soybean meal.

\section{MATERIALS AND METHODS}

\section{Animals and Diets}

Twelve multiparous Holstein cows, averaging $103 \pm$ 39 DIM and weighing $752 \pm 12.7 \mathrm{~kg}$ on the trial start date, were used to evaluate the various inclusion rates of SFSB in diets for lactating dairy cattle. Cows were blocked based on DIM and level of milk production into 4 blocks of 4 cows per group. Thereafter, within block, cows were randomly assigned to 1 of the 4 dietary treatments in a replicated $4 \times 4$ Latin square experimental design. One week of training for use of the Calan feeder doors (American Calan Inc., Northwood, $\mathrm{NH}$ ) was followed by four 28 -d periods. The first 14 d of each period were for adaptation to new dietary treatments and the final $14 \mathrm{~d}$ were for experimental data and sample collection.

The Calan Broadbent feeder door system and Calan Data Ranger (American Calan Inc.) were used to feed diets daily at $0800 \mathrm{~h}$ as a TMR. Cows had unlimited access to feed and water, except during milking. Prior to diet formulation, all forages were sampled and sent to Dairyland Laboratories (St. Cloud, MN) for nutrient analysis. Diets were formulated using AMINO Cow Mepron Ration Evaluator 3.5 (Degussa, Kennesaw, GA) to meet or exceed the requirements for a second lactation Holstein cow that is 90 DIM, has a BW of 750 $\mathrm{kg}$, has a BCS of 2.5 , and is producing $45.4 \mathrm{~kg}$ of milk, with $3.6 \%$ milk fat and $3.1 \%$ milk protein. Dietary treatments were the inclusion of SFSB as 0 (control), 5 , 10 , and $15 \%$ of diet DM (Table 1 ).

Steam-flaked soybeans were provided by Deluxe Feeds (EnRG Flakes; Sheldon, IA) and replaced a mixture of soybean meal, soy hulls, calcium salts of FA, and animal fat (SB mix; these blends were intended to be nearly identical in nutrient composition to SFSB; Table 2 ). The replacement occurred in such a way that $15 \%$ of dietary DM in all diets was made up of the SB mix, SFSB, or a combination of the 2 .

Brown midrib corn silage, alfalfa hay, and alfalfa haylage were used as forage sources and composed $60 \%$ of diet DM. Forages were premixed daily in a vertical mixer wagon and concentrates were prepared by New Vision Coop (Worthington, MN) and delivered when necessary. Concentrate was stored in bins at the farm and added to the Calan Data Ranger after the forage for each diet; this was followed by the addition of the necessary amounts of either the SB mix or SFSB. Concentrates were all manufactured in sufficient quantities at the beginning of the trial, stored at New Vision Coop, and then delivered to the research farm when needed. The amount of TMR offered and refused was recorded daily for each animal.

Cows were milk 3 times per day, at 0600, 1400, and $2100 \mathrm{~h}$, and daily milk production was recorded. Milk samples were collected from all 3 milkings on the last 2 $\mathrm{d}$ of each of the last $2 \mathrm{wk}$ of each period. Milk samples were composited in duplicate for each day based on the proportion of milk produced at each milking. One composite sample was sent to Heart of America DHIA Laboratory (Manhattan, KS) for compositional analysis using AOAC International (2002) approved methods. The other composite milk sample was retained for milk FA analysis by GC, which is described later.

Body weights were recorded at $3 \mathrm{~h}$ postfeeding for $2 \mathrm{~d}$ before the beginning of the first period and subsequently on the last $2 \mathrm{~d}$ of each experimental period. The $2 \mathrm{BW}$ were then averaged by period for statistical 
Table 1. Dietary treatments for cows fed increasing amounts of steam-flaked soybeans

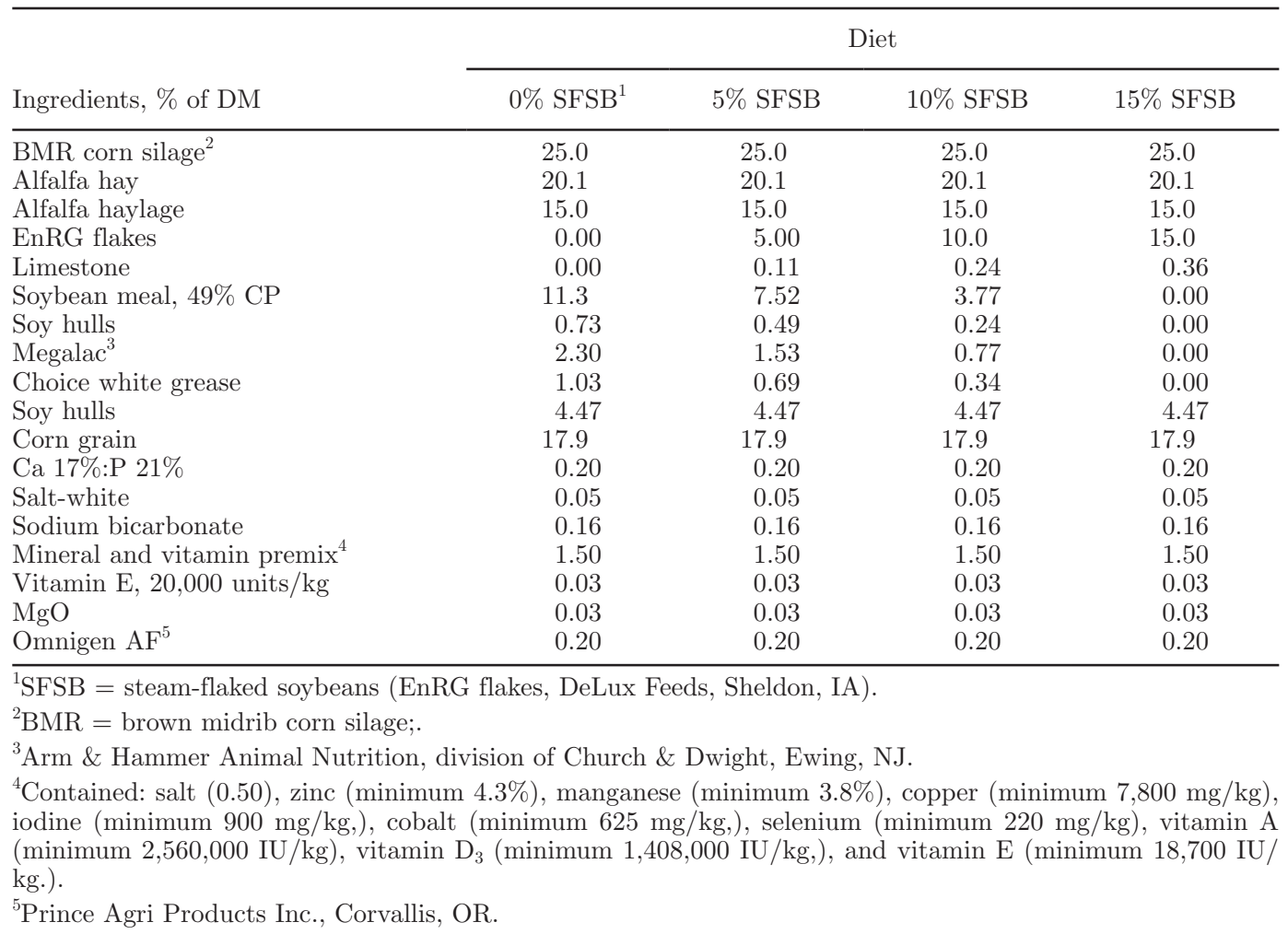

analysis. Body condition scores were assigned by 3 individuals using a 5-point system (Wildman et al., 1982) and rounding to the nearest quarter of a point. Values for BCS were then averaged by period for statistical analysis.

Samples of brown midrib corn silage, alfalfa hay, alfalfa haylage, SB mix, SFSB, and the base concentrate were collected once per week and stored at $-20^{\circ} \mathrm{C}$ until the end of each period, when they were thawed and composited by period. Samples were then dried for 48 $\mathrm{h}$ at $55^{\circ} \mathrm{C}$ in a forced-air oven (style V-23, Despatch Oven Co., Minneapolis, MN), ground through a 2-mm screen (Wiley mill, model 3; Arthur H. Thomas Co., Philadelphia, PA), and then through a 1-mm screen (Brinkman Instruments Co., Westbury, NY). Samples were subsequently analyzed for DM, ash, CP, crude fat, $\mathrm{NDF}, \mathrm{ADF}$, and FA composition.

\section{Chemical Analysis}

Dry matter content of TMR and of all ingredients was determined by drying $1 \mathrm{~g}$ of sample at $105^{\circ} \mathrm{C}$ for 4 h (AOAC International, 2002; method 934.01). Ash was determined by burning feed samples in a muffle fur-

Table 2. Nutrient contents of soybean mix and steam-flaked soybeans

\begin{tabular}{|c|c|c|c|c|c|c|}
\hline \multirow[b]{2}{*}{ Item } & \multicolumn{4}{|c|}{ Ingredients of soybean $\operatorname{mix}^{1}$} & \multirow{2}{*}{$\begin{array}{c}\text { Total of } \\
\text { soybean mix }\end{array}$} & \multirow[b]{2}{*}{$\mathrm{SFSB}^{2}$} \\
\hline & SBM & Soy hulls & CSFA & Animal fat & & \\
\hline $\mathrm{CP}, \%$ of $\mathrm{DM}$ & 49.0 & 13.1 & 0.00 & 0.00 & 36.7 & 37.6 \\
\hline $\mathrm{RDP}^{3} \%$ of $\mathrm{CP}$ & 70.0 & 70.0 & 0.00 & 0.00 & 70.0 & 70.0 \\
\hline $\mathrm{RUP}^{3} \%$ of $\mathrm{CP}$ & 30.0 & 30.0 & 0.00 & 0.00 & 30.0 & 30.0 \\
\hline $\mathrm{ADF}, \%$ of $\mathrm{DM}$ & 9.30 & 50.2 & 0.00 & 0.00 & 9.23 & 7.46 \\
\hline $\mathrm{NDF}, \%$ of $\mathrm{DM}$ & 14.0 & 66.5 & 0.00 & 0.00 & 13.5 & 12.9 \\
\hline NFC, $\%$ of DM & 28.2 & 13.6 & 0.00 & 0.00 & 21.4 & 23.5 \\
\hline Fat, \% of DM & 1.50 & 2.28 & 85.0 & 99.5 & 20.6 & 21.1 \\
\hline $\mathrm{NE}_{\mathrm{L}}, \mathrm{Mcal} / \mathrm{kg}$ & 2.09 & 1.39 . & 4.91 & 4.38 & 2.64 & 2.79 \\
\hline
\end{tabular}


nace at $600^{\circ} \mathrm{C}$ for $2 \mathrm{~h}$ according to AOAC International (2002; method 942.05). Crude protein was determined using Dumas nitrogen combustion via a rapid $\mathrm{N}$ cube (Elementar Americas, Inc., Mt. Laurel, NJ; AOAC International, 2002; method 968.06). Diets of 0, 5, 10, and $15 \%$ SFSB, as well as the SB meal mixture, were prepared for crude fat extraction via acid hydrolysis using the Ankom HCl Hydrolysis system kit, 120V (Ankom Technology, Macedon, NY). This was then followed up by solvent extraction of fat from all samples using ethyl ether by AOCS (2005) official procedure Am 5-04 (XT10, Ankom Technology). Concentrations of NDF and ADF were determined using the Ankom fiber analysis system (Ankom Technology). The method for NDF was based upon procedures described by Van Soest et al. (1991) using heat-stable $\alpha$-amylase and sodium sulfite. The method for ADF was based upon procedures described by Robertson and Van Soest (1981).

Fatty acid compositions of SFSB, SB mix, diets, and milk samples were determined by GC of butyl-esters of the FA samples. A modified Sukhija and Palmquist (1988) procedure described by Abdelqader et al. (2009) was used to prepare milk and feed FA samples; however, a $60^{\circ} \mathrm{C}$ heat block was used for the $90 \mathrm{~min}$ of incubation instead of $100^{\circ} \mathrm{C}$. Unpublished research demonstrated that lower incubation temperatures for longer times lead to decreased isomerization as well as more complete trans-esterification reaction (A. R. Hippen, personal communication). Prepared butylesters of FA were analyzed using a GC (model 6890, Hewlett-Packard, Palo Alto, CA). The injector port was at $230^{\circ} \mathrm{C}$ with a split ratio of $100: 1$. The column was $100 \mathrm{~m}$ long and had an inner diameter of $0.25 \mathrm{~mm}$ (Supelco 2560, Supelco Inc., Bellefonte, PA). Flow-rate of helium was $2.0 \mathrm{~mL} / \mathrm{min}$. Initial temperature of the column was $50^{\circ} \mathrm{C}$ and it was held at $50^{\circ} \mathrm{C}$ for $5 \mathrm{~min}$, this was followed by an increase in temperature to $145^{\circ} \mathrm{C}$ at a rate of $5^{\circ} \mathrm{C} / \mathrm{min}$. Temperature was held at $145^{\circ} \mathrm{C}$ for $30 \mathrm{~min}$ and subsequently increased to $190^{\circ} \mathrm{C}$ at a rate of $10^{\circ} \mathrm{C} / \mathrm{min}$. Temperature was held at $190^{\circ} \mathrm{C}$ for $30 \mathrm{~min}$, followed by the final increase at $5^{\circ} \mathrm{C} / \mathrm{min}$ to $210^{\circ} \mathrm{C}$, at which it was held for $40 \mathrm{~min}$. Individual FA were identified by comparison to known, commercially prepared reference standards (GLC-60, GLC-458, and GLC 606; $\mathrm{Nu}$-Chek Prep Inc., Elysian, MN). Milk samples used and reported in this manuscript were the final composite samples from each period and feed samples were the composite samples of each feedstuff from each period.

\section{Statistical Analysis and Calculations}

Data were analyzed as a replicated $4 \times 4$ Latin square and all production responses as well as FA com- positions were analyzed using the MIXED procedure of SAS (ver. 9.2, SAS Institute, Cary, NC). The following statistical model was adopted and used treatment, period, and interactions as fixed effects and cow as a random variable:

$$
\mathrm{Y}_{\mathrm{ijk}}=\mu+\mathrm{T}_{\mathrm{i}}+\mathrm{P}_{\mathrm{j}}+\mathrm{C}_{\mathrm{k}}+\mathrm{TP}_{\mathrm{ij}}+\mathrm{e}_{\mathrm{ijk}},
$$

where $Y_{\mathrm{ijk}}=$ the dependent variable, $\mu=$ overall mean, $\mathrm{T}_{\mathrm{i}}=$ fixed effect of dietary treatment ( $\mathrm{i}=1$ to 4$), \mathrm{P}_{\mathrm{j}}=$ fixed effect of period ( $\mathrm{j}=1$ to 4$), \mathrm{C}_{\mathrm{k}}=$ random effect of cow, $\mathrm{TP}_{\mathrm{ij}}=$ fixed effect of treatment and period interactions, and $\mathrm{e}_{\mathrm{ijk}}=$ residual error. Nonsignificant fixed effects were removed from the model in a step-wise manner. Polynomial orthogonal contrasts were used to test the linear, quadratic, and cubic effects of increasing dietary inclusion of SFSB. All data are presented as least squares means and separation of treatment means where interactions were found were completed using the PDIFF statement. Significance was declared at $P$ $<0.05$ and trends at $0.05 \leq P<0.10$.

\section{RESULTS}

Chemical composition of the treatment diets fed is provided in Table 3. Dietary content of myristic (C14:0), palmitic (C16:0), stearic (C18:0), cis-9 oleic acid (cis-9 C18:1) decreased as SFSB content increased. This was consistent with the lesser content of those FA in SFSB compared with the calcium salts of FA and choice white grease used in the SB mix. The content of cis-9, cis-12 C18:2 and $\alpha-C 18: 3$ increased as SFSB were increased in the diet and is the result of the greater content of those PUFA in steam-flaked soybeans.

Dry matter intake, actual and ECM yields, milk fat, protein and lactose contents, and milk fat and protein yields were similar for all diets (Table 4 ). Concentration of MUN decreased $(P<0.01)$ as SFSB increased in the diet. Somatic cell score was not significantly influenced by the varying dietary treatments. Furthermore, feed efficiency was similar in all treatments at approximately $1.4 \mathrm{~kg}$ of ECM $/ \mathrm{kg}$ of DMI. Body weight and BCS were not affected by dietary content of SFSB; however, a linear increase and decrease in change in BW and change in BCS were observed, respectively.

Short- and medium-chain FA in milk fat, with the exception of C14:1, increased as steam-flaked soybeans in the diet increased (Table 5). Both C16:0 and C16:1 decreased linearly as the amount of SFSB in the diet increased. Long-chain and SFA increased in milk fat as SFSB within the diet increased. Increasing SFSB content also led to decreased MUFA and increased PUFA. Stearic acid (C18:0) increased when greater amounts of 
Table 3. Chemical composition of dietary components and experimental diets

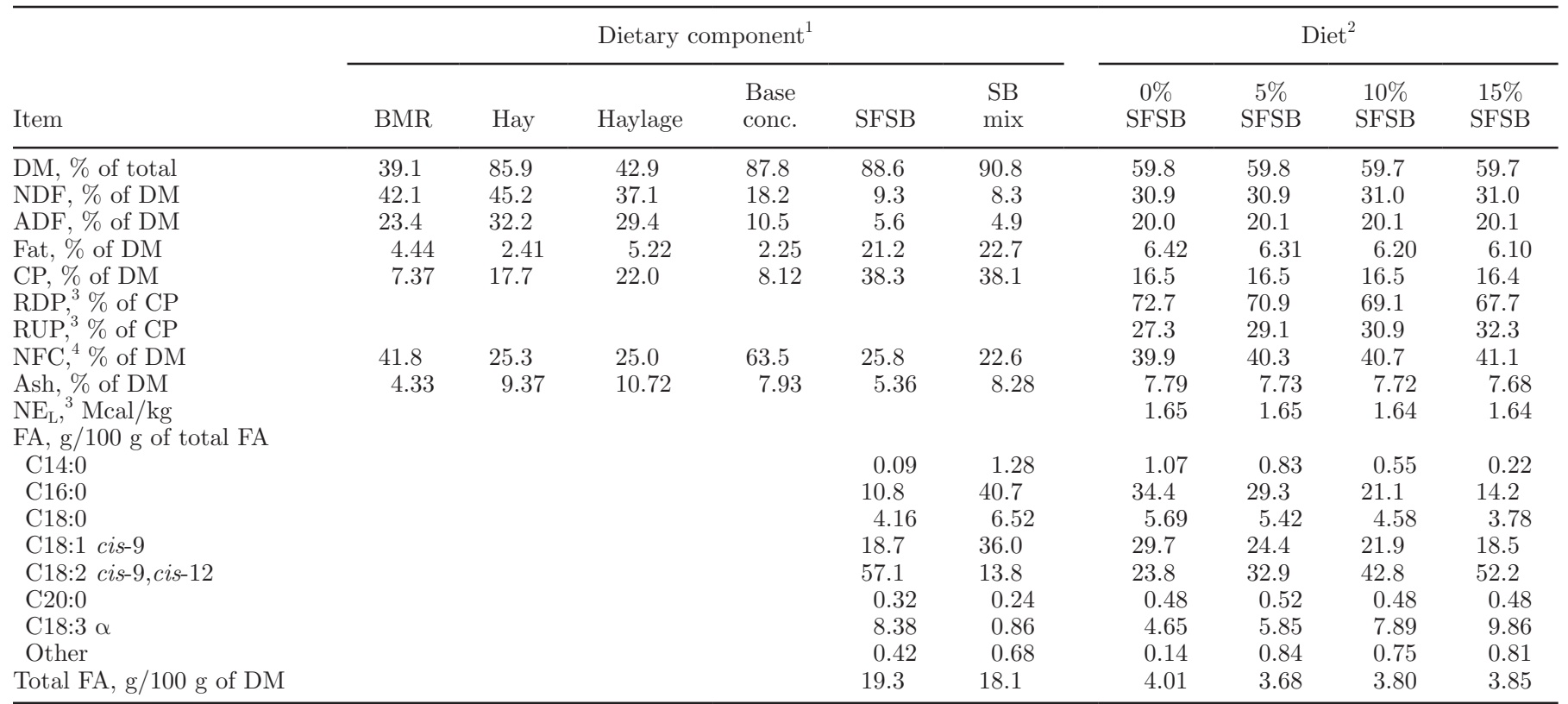

${ }^{1}$ Wet chemical analysis of individual ingredients; BMR $=$ brown midrib corn silage; base conc. $=$ base concentrate; SFSB $=$ steam-flaked soybeans; SB mix = mixture of SBM, calcium salts of fatty acids, animal fat, and soy hulls.

${ }^{2}$ Diet recomposition using ration formulation software (AMINO Cow Mepron Ration Evaluator 3.5; Degussa, Kennesaw, GA).

${ }^{3}$ Estimated from NRC (2001).

${ }^{4} \mathrm{NFC}=100-(\mathrm{NDF}+$ protein + fat + ash $)$.

Table 4. Least squares means of production parameters for lactating cows fed increasing amounts of steam-flaked soybeans

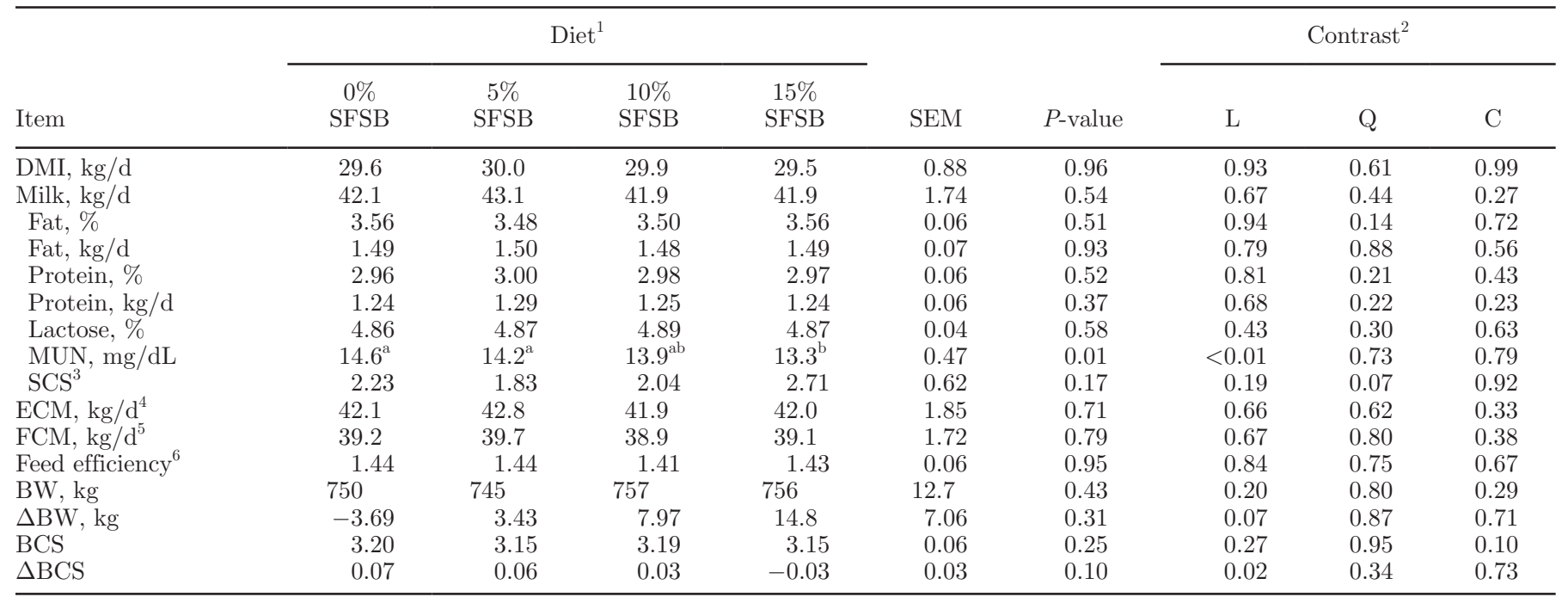

${ }_{\mathrm{a}, \mathrm{b}}$ Means within a row with different superscripts differ significantly $(P<0.05)$.

${ }^{1} \mathrm{SFSB}=$ steam-flaked soybeans.

${ }^{2} \mathrm{~L}=$ linear contrasts; $\mathrm{Q}=$ quadratic contrasts; $\mathrm{C}=$ cubic contrasts.

${ }^{3} \mathrm{SCS}=\log _{2}(\mathrm{SCC} / 100)+3$.

${ }^{4} \mathrm{ECM}=($ milk $\times 0.327)+($ fat yield $\times 12.95)+($ protein yield $\times 7.20)$.

${ }^{5} \mathrm{FCM}=(0.4 \times$ milk $)+(15 \times$ fat yield $)$.

${ }^{6}$ Feed efficiency $=$ ECM $/$ DMI. 
Table 5. Milk FA content from cows fed increasing amounts of steam-flaked soybeans (SFSB)

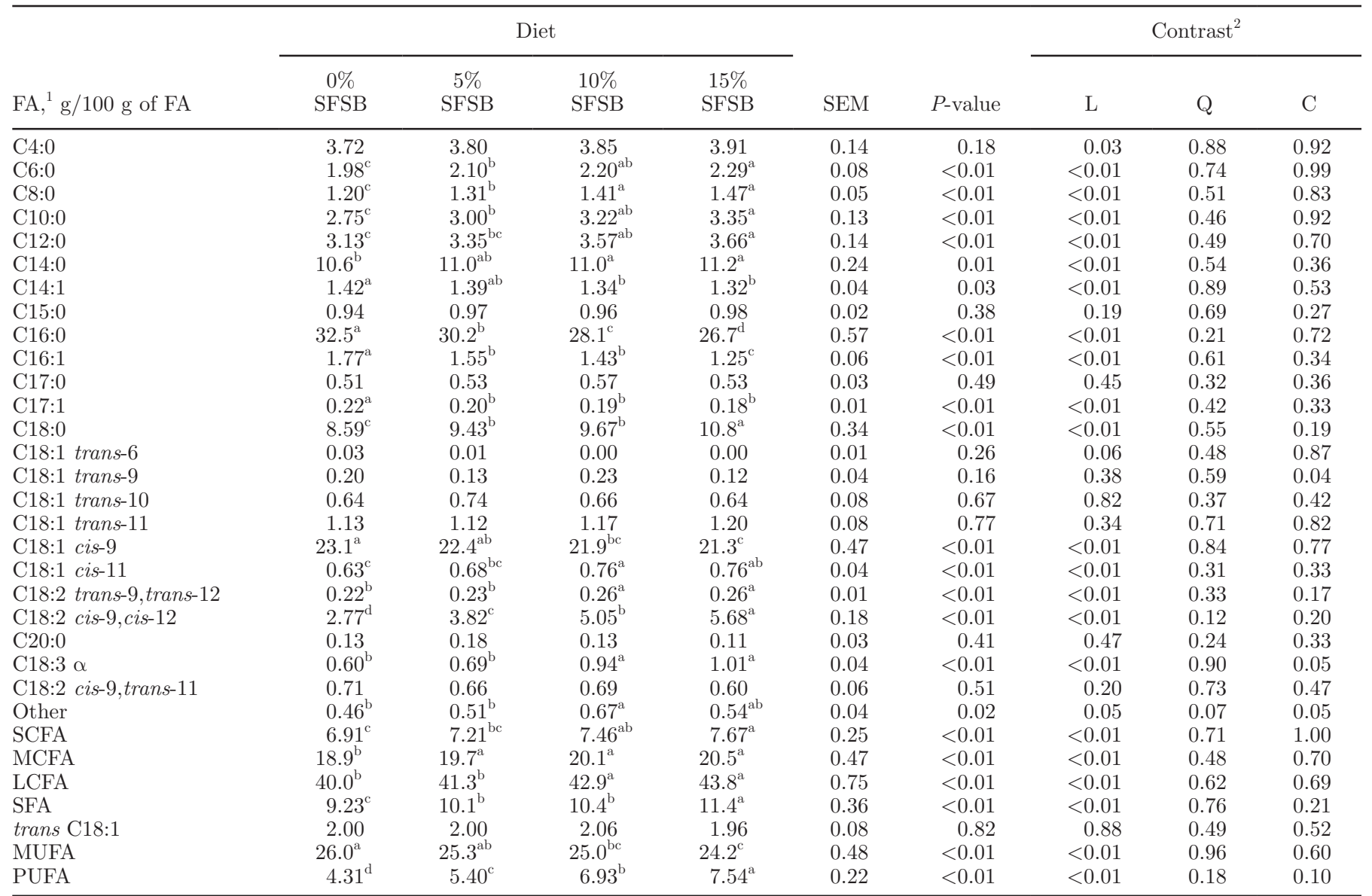

${ }^{\mathrm{a}-\mathrm{d}}$ Means within a row with different superscripts differ significantly $(P<0.05)$.

${ }^{1}$ Other $=$ FA $>$ C20:0; SCFA $=$ short-chain fatty acids (C4:0-C8:0); MCFA = medium-chain fatty acids $($ C10:0-C16:0); LCFA = long-chain fatty acids $(\geq \mathrm{C} 16: 0)$.

${ }^{2} \mathrm{~L}=$ Linear contrasts; $\mathrm{Q}=$ quadratic contrasts; $\mathrm{C}=$ cubic contrasts.

SFSB were added to the diet. Similarly, cis-11 C18:1, trans-9,trans-12 C18:2, and $\alpha-\mathrm{C} 18: 3$ were greater when SFSB in the diet were greater. cis-9 C18:1 decreased by nearly 2 percentage units as SFSB increased from 0 to $15 \%$ of DM. Diet had no significant effect on transC18:1 FA.

\section{DISCUSSION}

Overall, adding SFSB did not increase milk production as we hypothesized. This may have been because RUP values of the diets were only modestly increased because RUP and total-tract protein digestibility were slightly greater for SFSB (42 and 98.9\% of CP, respectively) than for SB meal (30 and $95.4 \%$, respectively; Bruns et al., 2011). It is likely that the microbial protein and RUP requirements of the animals were being met by the control (i.e., SB meal) diet. Realistically, the control diet was formulated to be nearly identical in nutrient composition to the SFSB diets, thus any differences from the control diet would be minimal at most. This could also indicate inadequate heat was present within the SFSB processing such that RUP of diets was improved only from 27 to $32 \%$ of CP (Table 3), which was likely not enough to be effective (NRC, 2001). Incidences of inadequate processing were reported when feeding roasted soybeans with no improved production (Stern et al., 1985; Scott et al., 1991; Neves et al., 2006), even though several other studies (Faldet and Satter, 1991; Knapp et al., 1991) showed an increase in milk production when roasting at higher temperatures (146 and $149^{\circ} \mathrm{C}$, respectively) than Scott et al. (1991), who roasted at $130^{\circ} \mathrm{C}$. The result of the higher temperatures is increased RUP values (Lykos and Varga, 1995). This could be similar to what is occurring here, although it is more likely that the control diet was adequately meeting the dietary requirements of the cows, as observed in Bruns et al. (2011), the whole SFSB fed in the present 
study contained increased RUP ( $42 \%$ of CP) compared with raw soybeans ( $21 \%$ of $\mathrm{CP}$ ) and solvent-extracted soybean meal ( $30 \%$ of $\mathrm{CP})$.

Milk urea nitrogen concentration decreased as SFSB increased in the diet. This subtle but significant linear response possibly indicated increased efficiency of nitrogen utilization of SFSB relative to the SB mix, possibly because of decreased ruminal ammonia as a result of greater RUP in SFSB relative to soybean meal (Bruns et al., 2015).

Milk fat concentration is seldom affected when oilseeds are fed, but it is usually decreased when oil is fed (Mohamed et al., 1988). Concentrations of short- and medium-chain FA, with the exception of C14:1, generally increased as the amount of SFSB in the diet increased. This change in composition is opposite of what other researchers (Ramaswamy et al., 2001; AbuGhazaleh et al., 2002) found when full-fat extruded soybeans were added to diets, but was likely because the use of animal fat and calcium salts of FA as the control fat led to decreased de novo synthesis of FA with those diets (Wu et al., 1993; Petit et al., 2001), resulting in the relatively higher amounts of short- and medium-chain FA seen as dietary SFSB increased. Thus, FA content of the milk fat varied somewhat but total milk fat content did not change. It appeared that the presence of unsaturated FA from SFSB may not be as detrimental to rumen microbes as has been previously observed in other soybean feeding studies (Ramaswamy et al., 2001; AbuGhazaleh et al., 2002) because of less biohydrogenation of FA in SFSB in the rumen than with extruded soybeans. Palmitic acid (C16:0) decreased as the content of SFSB increased in our study, which was likely a direct effect of the decreased content of this FA in the diet (Table 3). However, stearic acid (C18:0) increased as SFSB made up a greater proportion of the diet, which indicated more complete biohydrogenation of FA as SFSB were added to the diet because dietary content of stearic acid decreased as SFSB increased. Trans-C18:1 FA as well as cis-9,trans-11 CLA were not affected by dietary treatment which reflected less interference with ruminal biohydrogenation. This was not expected because, in other studies where soybeans were fed, trans-11 C18:1 and cis-9,trans-11 CLA increased (Ramaswamy et al., 2001; AbuGhazaleh et al., 2002; Li et al., 2009). Less interference with ruminal metabolism by SFSB than by other heated soybean products, such as extruded soybeans, implies that the soybean structure was not as extensively altered by steam flaking as by extrusion (Scott et al., 1991). This was reflected in such things as no change in milk fat concentration and minimal changes in milk FA concentrations. Cis-9 C18:1 decreased linearly as SFSB were increased in the diet, and cis-9,cis-12 C18:2 as well as $\alpha$-C18:3 increased by 2 -fold as SFSB were increased from 0 to $15 \%$ of dietary DM. These results indicated that the milk FA profiles in our study were more or less a reflection of dietary treatment. This may imply that lipids in SFSB may be less detrimental on ruminal fermentation than other full-fat soybean sources. This would also support the increased content of short- and medium-chain FA, if the majority of unsaturated FA were protected, then they would not have a great effect on rumen microbes or de novo milk fat synthesis.

\section{CONCLUSIONS}

Steam-flaked soybeans can replace a mixture of soybean meal and commercial fat sources while maintaining milk, milk fat, and milk protein production and decreasing MUN concentrations. Unlike some other soybean supplements, feeding SFSB did not increase trans-11 C18:1 or cis-9,trans-11 CLA, but instead resulted in increased cis-9,cis-12 C18:2 and $\alpha$-C18:3. Additionally, SFSB may be a source fat that is more ruminally inert than some other soybean sources.

\section{ACKNOWLEDGMENTS}

The authors express appreciation to the farm crew and personnel at the South Dakota State University Dairy Teaching and Research Facility, Brookings, for care of the animals and to fellow graduate students for assistance with sample collection. The authors gratefully acknowledge Deluxe Feeds (EnRG Flakes), Sheldon, Iowa, for supplying the steam-flaked soybeans used in this research and for partial financial support. In memoriam, the authors gratefully acknowledge the role that the late Arnold Hippen had in planning and directing this research.

\section{REFERENCES}

Abdelqader, M. M., A. R. Hippen, K. F. Kalscheur, D. J. Schingoethe, K. Karges, and M. L. Gibson. 2009. Evaluation of corn germ from ethanol production as an alternative fat source in dairy cow diets. J. Dairy Sci. 92:1023-1037.

AbuGhazaleh, A. A., D. J. Schingoethe, A. R. Hippen, and K. F. Kalscheur. 2004. Conjugated linoleic acid increased in milk when cows fed fish meal and extruded soybeans for an extended period of time. J. Dairy Sci. 87:1758-1766.

AbuGhazaleh, A. A., D. J. Schingoethe, A. R. Hippen, K. F. Kalscheur, and L. A. Whitlock. 2002. Fatty acid profiles of milk and rumen digesta from cows fed fish oil, extruded soybeans or their blend. J. Dairy Sci. 85:2266-2276.

AlZahal, O., N. E. Odongo, T. Mutsvangwa, M. M. Or-Rashid, T. F. Duffield, R. Bagg, P. Dick, G. Vessie, and B. W. McBride. 2008. Effects of monensin and dietary soybean oil on milk fat percentage and milk fatty acid profile in lactating dairy cows. J. Dairy Sci. 91:1166-1174.

AOAC International. 2002. Official Methods of Analysis. AOAC International, Gaithersburg, MD. 
AOCS. 2005. Official Procedure: Approved Procedure Am 5-04Rapid determination of oil/fat utilizing high temperature solvent extraction. American Oil Chemists Society (AOCS), Urbana, IL.

Bauman, D. E., and J. M. Griinari. 2003. Nutritional regulation of milk fat synthesis. Annu. Rev. Nutr. 23:203-227.

Bruns, H. R., K. J. Herrick, K. F. Kalscheur, D. J. Schingoethe, R. Rosenboom, and A. R. Hippen. 2011. Ruminal degradation and intestinal protein digestion of steam-flaked soybeans. J. Dairy Sci. 94(E-Suppl. 1):116-117. (Abstr.)

Chouinard, P. Y., V. Girard, and G. J. Brisson. 1997a. Performance and profiles of milk fatty acids of cows fed full fat, heat-treated soybeans using various processing methods. J. Dairy Sci. 80:334342 .

Chouinard, P. Y., J. Levesque, V. Girard, and G. J. Brisson. 1997b. Dietary soybeans extruded at different temperatures: milk composition and in situ fatty acid reactions. J. Dairy Sci. 80:2913-2924.

Faldet, M. A., and L. D. Satter. 1991. Feeding heat-treated full-fat soybeans to cows in early lactation. J. Dairy Sci. 74:3047-3054.

Knapp, D. M., R. R. Grummer, and M. R. Dentine. 1991. The response of lactating dairy cows to increasing levels of whole roasted soybeans. J. Dairy Sci. 74:2563-2572.

Li, Y., A. Diao, and Q. Meng. 2009. The effect of steam-flaked and extruded full-fat soybeans on the concentration of conjugated linoleic acid in the milk fat of dairy cows. Arch. Anim. Nutr. 63:243-253.

Lundy, F. P. III, E. Block, W. C. Bridges Jr., J. A. Bertrand, and T. C. Jenkins. 2004. Ruminal biohydrogenation in Holstein cows fed soybean fatty acids as amides or calcium salts. J. Dairy Sci. $87: 1038-1046$

Lykos, T., and G. A. Varga. 1995. Effects of processing method on degradation characteristics of protein and carbohydrate sources in situ. J. Dairy Sci. 78:1789-1801.

Mohamed, O. E., L. D. Satter, R. R. Grummer, and F. R. Ehle. 1988. Influence of dietary cottonseed and soybean on milk production and composition. J. Dairy Sci. 71:2677-2688.

NRC. 2001. Nutrient Requirements of Dairy Cattle. 7th rev. ed. Natl. Acad. Sci., Washington, DC

Neves, C. A., G. T. Santos, M. Matsushita, E. M. Alves, R. L. Oliveira, A. F. Branco, D. C. Silva, A. C. Furlan, and H. V. Petit. 2006. Intake, whole tract digestibility, milk production, and milk composition of Holstein cows fed extruded soybeans treated with or without lignosulfonate. Anim. Feed Sci. Technol. 134:32-44.

Petit, H. V., R. J. Dewhurst, J. G. Proulx, M. Khalid, W. Haresign, and $\mathrm{H}$. Twagiramungu. 2001. Milk production, milk composition, and reproductive function of dairy cows fed different fats. Can. J. Anim. Sci. 81:263-271.

Pires, A. V., M. L. Eastridge, and J. L. Firkins. 1996. Roasted soybeans, blood meal and tallow as sources of fat and ruminally undegradable protein in the diets of lactating cows. J. Dairy Sci. 79:1603-1610.
Ramaswamy, N., R. J. Baer, D. J. Schingoethe, A. R. Hippen, K. M. Kasperson, and L. A. Whitlock. 2001. Composition and flavor of milk and butter from cows fed fish oil, extruded soybeans or their combination. J. Dairy Sci. 84:2144-2151.

Reddy, P. V., J. L. Morrill, and T. G. Nagaraja. 1994. Release of free fatty acids from raw or processed soybeans and subsequent effects on fiber digestibilities. J. Dairy Sci. 77:3410-3416.

Robertson, J. B., and P. J. Van Soest. 1981. The detergent system of analysis and its application to human foods. Pages 123-158 in The Analysis of Dietary Fiber in Food. W. P. T. James and O. Theander, ed. Marcel Dekker Inc., New York, NY.

Schingoethe, D. J., M. J. Brouk, K. D. Lightfield, and R. J. Baer. 1996. Lactational responses of dairy cows fed unsaturated fat from extruded soybeans or sunflower seeds. J. Dairy Sci. 79:1244-1249.

Schingoethe, D. J., D. P. Casper, C. Yang, D. J. Illg, J. L. Sommerfeldt, and C. R. Mueller. 1988. Lactational response to soybean meal, heated soybean meal, and extruded soybeans with ruminally protected methionine. J. Dairy Sci. 71:173-180.

Scott, T. A., D. K. Combs, and R. R. Grummer. 1991. Effects of roasting, extrusion, and particle size on the feeding value of soybeans for dairy cows. J. Dairy Sci. 74:2555-2562.

Stern, M. D., K. A. Santos, and L. D. Satter. 1985. Protein degradation in rumen and amino acid absorption in small intestine of lactating dairy cattle fed heat-treated whole soybeans. J. Dairy Sci. 68:45-56.

Sukhija, P. S., and D. L. Palmquist. 1988. Rapid method for determination of total fatty acid content and composition of feedstuffs and feces. J. Agric. Food Chem. 36:1202-1206.

Van Soest, P. J., J. B. Robertson, and B. S. Lewis. 1991. Methods for dietary fiber, neutral detergent fiber, and nonstarch polysaccharides in relation to animal nutrition. J. Dairy Sci. 74:3583-3597.

Waltz, D. M., and M. D. Stern. 1989. Evaluation of various methods for protecting soya-bean protein from degradation by rumen bacteria. Anim. Feed Sci. Technol. 25:111-122.

Wildman, E. E., G. M. Jones, P. E. Wagner, R. L. Boman, H. F. Troutt Jr., and T. N. Lesch. 1982. A dairy cow body condition scoring system and its relationship to standard production characteristics. J. Dairy Sci. 65:495-501.

Wu, Z., J. T. Huber, F. T. Sleiman, J. M. Simas, K. H. Chen, S. C. Chan, and C. Fontes. 1993. Effect of three supplemental fat sources on lactation and digestion in dairy cows. J. Dairy Sci. 76:3562-3570.

Zheng, H. C., J. X. Liu, J. H. Yao, Q. Yuan, H. W. Ye, J. A. Ye, and Y. M. Wu. 2005. Effects of dietary sources of vegetable oils on performance of high-yielding lactating cows and conjugated linoleic acids in milk. J. Dairy Sci. 88:2037-2042. 